\title{
Histórico sobre a Comissão do Melhoramento do Rio São Francisco e a Usina Hidrelétrica de Sobradinho
}

\author{
Ítala Rayane de Castro Machado ${ }^{1}$ e Ivoneide de França Costa ${ }^{2}$. \\ 1. Bolsista PIBIC/CNPq, Graduando em Engenharia Civil, Universidade Estadual de Feira de Santana, e-mail: \\ italacastro03@gmail.com \\ 2. Orientador, Departamento de Letras e Artes, Universidade Estadual de Feira de Santana, e-mail: \\ neidefc@uefs.br
}

PALAVRAS-CHAVE: comissão; hidrelétrica; Sobradinho.

\section{INTRODUÇÃO}

Em 1882, o governo imperial teve a intenção de gerar um sistema de transporte utilizando as vias de comunicação fluvial nas regiões relacionadas com o Vale do Rio São Francisco. Porém, o trecho era de difícil navegação, principalmente devido as áreas encachoeiradas, o que foi necessário efetuar melhoramentos do rio, pela Comissão de Melhoramento do Rio São Francisco (CMRSF).

A partir disso, também buscaram extrair outros potenciais do rio, principalmente em trechos em que não tiveram melhoramento satisfatórios para a possível navegação regular, o que foi a situação da cachoeira do Sobradinho, onde foi aproveitado o potencial hidrelétrico, com a construção de barragem.

\section{MATERIAL E MÉTODOS OU METODOLOGIA (ou equivalente)}

Foi feita uma pesquisa bibliográfica sobre a história e métodos usados para a desobstrução do Rio São Francisco, como também os métodos de construção da barragem e hidrelétrica de Sobradinho, tendo como ponto de partida os trabalhos da CMRSF. Tal pesquisa foi realizada na documentação do Arquivo Nacional do Rio De janeiro (ANRJ) e em outras diversas fontes bibliográficas sobre o tema.

\section{RESULTADOS E/OU DISCUSSÃO (ou Análise e discussão dos resultados)}

A CMRSF começou os trabalhos em 1883, com sondagens, levantamentos de plantas, nivelamento e determinação de velocidade das correntes marítimas, seguida com serviço de desobstrução e da construção de diques. As atividades da comissão tiveram início pelas cachoeiras de Sobradinho, que ficam acima 8 léguas de Juazeiro.

Ao decorrer das obras do melhoramento, a comissão foi dividida em algumas turmas com diferentes funções, com a intenção de aumentar a velocidade dos trabalhos. As obras de desobstrução do rio, no geral, se destacavam em: Fechamento de saídas laterais para impedir a saída de agua do canal específico que for escolhido; construção de molhes com a intenção de desviar um certo volume de agua para o canal que estiver sendo adaptado; formação de rampas e corredeiras, com o propósito de concentrar a agua e guiar correntes, de modo separar através de cachoeiras locais e levantar os níveis das aguas de maneira a aumentar a profundidade de diques ou paredões; e na remoção de rochas que obstruem a passagem e no revestimento de alguns pontos, onde a corrente da água for erosão. E enquanto inaptos a praticar trabalhos em 
campo, a comissão praticava trabalhos de escritório, como construções de plantas, desenhos de curvas meteorológicas, cálculos para conhecer o volume de água que certo molhe faz desviar para algum canal (ANRJ; 1883-1884)

Após algumas etapas de desobstrução, foram feitos testes de navegação no primeiro trecho melhorado, que foi de Sant'Anna até Boa Vista, tendo se verificado o bom êxito dos trabalhos por meio de 53.387 sondagens, observando que o canal estava apto a navegação a vapor. $\mathrm{O}$ que influenciou o governo imperial solicitar o orçamento das obras para os anos seguintes.

A Comissão enfrentou alguns impedimentos para prosseguimento e rapidez das obras, recomeçando as obras com fraco impulso, impedimentos esses como: Falta de materiais para o serviço, o que dependia da verba enviada pelo governo, verba essa que nem sempre era enviada no prazo, ou em quantia necessária, e também acontecimentos naturais, como dias chuvosos ou diversos dias de cheia do rio.

Em 1896, a empresa Viação Brasil constatou que considerava essencial conservar os serviços executados na cachoeira do Sobradinho e de Santana, visto que essa área não teve melhoramento algum e continuavam sendo grandes obstáculos para a navegação regular, causando danos aos vapores. Para ultrapassar as cachoeiras, era necessário fazer baldeação, o que causava incomodo aos passageiros e mais gastos para a empresa. Como solução, a empresa propôs ao Governo Federal alternativas, uma seria a construção de ramal ferroviário, que partiria de um ponto da via férrea de Salvador ao São Francisco e iria até Oliveira, ou a transformação radical do trecho encachoeirado do rio.

Com isso, os trabalhos da comissão, e a Comissão, foram finalizados por ato do ministro da Viação em 1896, por não houver melhoramento algum em alguns dos trechos trabalhados no rio, o que se tornavam grandes contratempos para navegação.

\section{CONSIDERAÇÕES FINAIS (ou Conclusão)}

As informações históricas obtidas mostram que, apesar de o melhoramento não ter alcançado o objetivo traçado pelo governo, que seria a possível navegação estável pelo decurso do rio, foram descobertos novos meios de aproveitamento do trecho, como a barragem de Sobradinho e num segundo momento a hidrelétrica. A Usina de Sobradinho foi de grande influência para a interligação das regiões Nordeste e Norte através da transmissão entre Sobradinho e Tucuruí, sabendo que a cidade de Belém do Pará e cidades vizinhas, foram abastecidas com energia elétrica gerada no Sobradinho, proporcionando significativa economia de petróleo.

De tal maneira que a geração hidrelétrica ocupa lugar de destaque dentro dos serviços oferecidos pelo São Francisco, visto que no geral os reservatórios possuem finalidades múltiplas, que além da geração de energia, regulariza o rio, proporcionando navegação em vasto trecho do rio e possibilita a transposição de suas aguas para as regiões áridas do Nordeste. Portanto, a bacia deste rio é de vital importância para o desenvolvimento socioeconômico da região Nordeste do Brasil.

\section{REFERÊNCIAS}


LISBOA, Alfredo. O Exame Feito as Obras do Melhoramento do Alto S. Francisco. Rio de janeiro: Imprensa Nacional, 1889, p. 10

A Engenharia no Brazil. In: Revista de Engenharia. Rio de Janeiro: Anno I, n. 3. Setembro de 1879, pp. 1-2.

AMARANTE, Antônio Plácido do. Exposição sobre o melhoramento da parte encachoeirada do rio S. Francisco, entre a cachoeira de Sobradinho e Jatobá - 428 quilômetros, março de 1883.

COSTA, Ivoneide de França Costa. Comissão Hidráulica do Império (1879-1880): profissionalização e técnica a serviço dos melhoramentos no século XIX. Tese (Doutorado em História das Ciências) - Programa de Pós-Graduação em História das Ciências e das Saúde - COC - Fiocruz, Rio de Janeiro. 2013, p.187

Arquivo Nacional do Rio De Janeiro (ANRJ); Lembrete Diário da CMRSF referente aos anos de 1883-1884, pasta $\mathrm{n}^{\circ} 57$, diário 57-1, (manuscrito)

ANRJ; Lembrete Diário da CMRSF referente ao ano de 1884, pasta nº 57, diário 57-1, (manuscrito)

PEREIRA, Geraldo Magela. Projeto de Usinas Hidrelétricas: Passo a passo. Minas Gerais: Oficina de Textos: 2015, p. 77 